\title{
Effect of Growth Regulator on Growth, Yield and Seed Quality Parameters of Okra (Abelmoschus esculentus L.): cv. Utkal Gaurav
}

\author{
Kanhaiyalal Sanodiya $^{1 *}$, Geeta Pandey ${ }^{2}$, Prafull Kacholli ${ }^{1}$ and Ashish Kumar Dubey ${ }^{3}$ \\ ${ }^{1}$ Department of Vegetable Science, Collage of Agriculture, Orissa University of Agriculture and \\ Technology, Bhubaneswar-751003, Odisha, India \\ ${ }^{2}$ Department of Floriculture and Landscaping, Collage of Agriculture, Orissa University of \\ Agriculture and Technology, Bhubaneswar-751003, Odisha, India \\ ${ }^{3}$ Indira Gandhi National Tribal University, Amarakantak-484224, Madhya Pradesh, India \\ *Corresponding author
}

\begin{tabular}{|c|c|}
\hline & A B S T R A C T \\
\hline & \multirow{5}{*}{ 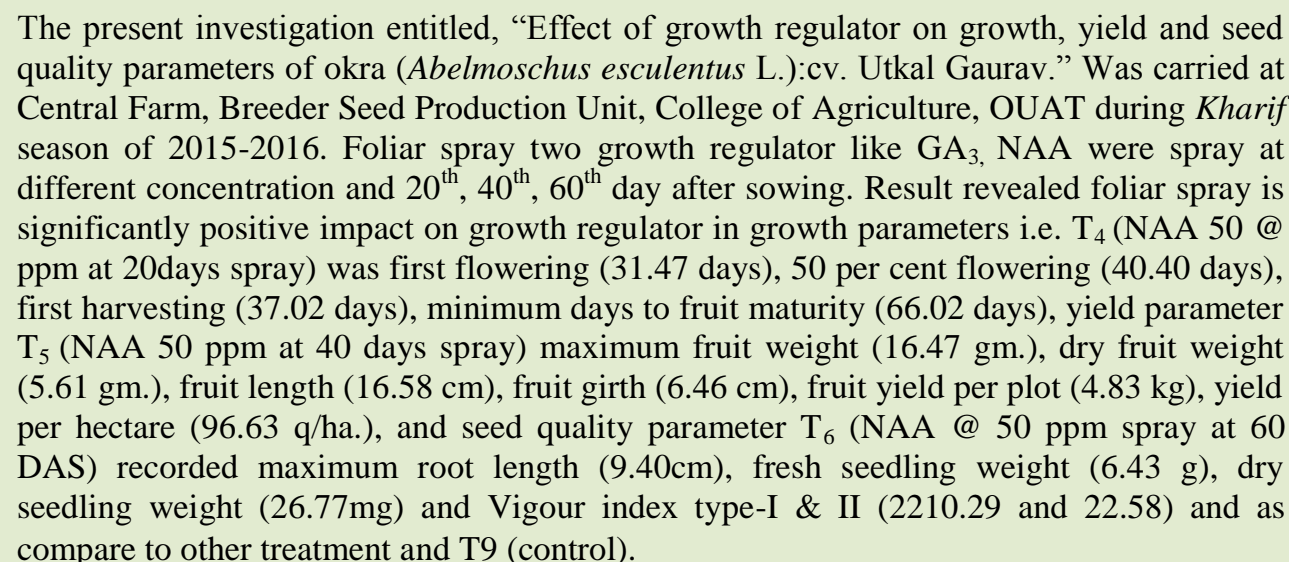 } \\
\hline & \\
\hline $\begin{array}{l}\text { Effect, Growth } \\
\text { regulator growth } \\
\text { yield seed quality } \\
\text { parameter of okra. }\end{array}$ & \\
\hline Article Info & \\
\hline $\begin{array}{l}\text { Accepted: } \\
\text { 28 September } 2017 \\
\text { Available Online: } \\
10 \text { October } 2017\end{array}$ & \\
\hline
\end{tabular}

\section{Introduction}

Okra, lady's finger (Abelmoschus esculentus L.), $2 \mathrm{n}=2 \mathrm{x}=130$ Okra is an important vegetable crop having good demand throughout the year for its tender fruits and consider as one of the major vegetable crops of the tropical and subtropical parts of the world.

Plant growth regulators are the organic substances which are produced naturally in plants, synthesized in one part and usually translocated to other part where every small quantity influence the growth and other physiological function of the plants (Taiz et al., 2010).

Okra is a heavy yielder and high remunerative crop but sometimes grower suffer with recurring economic loss due to poor plant vigour, low pod setting and small pod size. Therefore, besides varieties evaluation, standardization of location specific approach 
is essential to improve productivity of okra. Growth regulator is considered to be a key factor in vegetative growth, flowering, pod setting and high yield in okra (Singh et. al. 2012).

The growth regulators and their uses are considered to be the most technical and scientific in crop production. The selection of right hormones, their appropriate concentration and their time and method of application are most essential. Even the same growth regulator in different concentrations brings about the different results. Due to high rise in the prices of chemical fertilizers and also to maintain the eco-system of soil, it has become necessary to use eco-friendly chemicals like $\mathrm{GA}_{3}$, NAA and IBA. Hence the present investigation has been undertaken to find out the effect of certain growth regulators viz., $\mathrm{GA}_{3} 50$ ppm, NAA 50 ppm were spray at different day after sowing $20^{\text {th }}, 40^{\text {th }}, 60^{\text {th }}$ day after sowing.

\section{Materials and Methods}

The experiment was conducted during kharif season 2015-16 was carried at Central Farm, Breeder Seed Production Unit, College of Agriculture, OUAT. The experiment was laid out in Randomized Block Design with three replications and nine treatments including growth regulators as $\mathrm{GA}_{3} 50 \mathrm{ppm}$, NAA 50 ppm were spray at $20^{\text {th }}, 40^{\text {th }}, 60^{\text {th }}$ day after sowing and one control. The seeds of okra were sown in the main field with recommended package of practices. Observations are collected on the growth of crop in ten randomly selected plants in an each plot.

Treatment details given are below.

$\mathrm{T}_{1}=$ Foliar spray of $50 \mathrm{PPM} \mathrm{GA}_{3}$ at $20 \mathrm{DAS}$

$\mathrm{T}_{2}=$ Foliar spray of $50 \mathrm{PPM} \mathrm{GA}_{3}$ at $40 \mathrm{DAS}$
$\mathrm{T}_{3}=$ Foliar spray of $50 \mathrm{PPM} \mathrm{GA}_{3}$ at $60 \mathrm{DAS}$

$\mathrm{T}_{4}=$ Foliar spray of 50 PPM NAA at 20 DAS

$\mathrm{T}_{5}=$ Foliar spray of 50 PPM NAA at 40 DAS

$\mathrm{T}_{6}=$ Foliar spray of 50 PPM NAA at 60 DAS

$\mathrm{T}_{7}=$ Foliar spray of $\mathrm{GA}_{3} 20 \mathrm{PPM}$ at $20 \mathrm{DAS}+$ NAA 50 PPM at 40 DAS

$\mathrm{T}_{8}=$ Foliar spray of NAA 40 PPM at 20 DAS

$+\mathrm{GA}_{3} 50 \mathrm{PPM}$ at $40 \mathrm{DAS}$

$\mathrm{T}_{9}=$ Control

The vigour index values were calculated as per the method prescribed by Abdul-Baki and Anderson (1973) and expressed in whole number.

Vigour index Type-I = Germination (\%) $\mathrm{x}$ mean seedling length $(\mathrm{cm})$

Vigour index Type-II = Germination (\%) $\mathrm{x}$ mean seedling dry weight $(\mathrm{g})$

\section{Results and Discussion}

The results obtained from the present investigation as well as relevant discussion have been summarized under following heads

Effect of foliar spray of growth regulators on different growth parameters in Okra cv. Utkal Gaurav

The data presented in (Table 1) revealed the significant effect of growth regulators on growth parameters at $\mathrm{T}_{2}\left(\mathrm{GA}_{3} @ 50 \mathrm{ppm}\right.$ at 40 DAS) where maximum plant height $(107.97 \mathrm{~cm})$ was recorded, followed by $\mathrm{T}_{5}$ (NAA @ 50 ppm at 40 DAS) plant height $(104.31 \mathrm{~cm})$. Minimum plant height was recorded on $\mathrm{T}_{9}$ (control treatment). Similar result was reported by Rani et al., (2013), 
Patil and Patel 2010 and The application of growth promoters increased the plant height due to enhancement in the cell division and cell elongation at shoot apex and such effect was due to increase in photosynthetic efficiency (Taiz et al., 2010). The maximum stem girth $(5.68 \mathrm{~cm})$ was recorded in $\mathrm{T}_{4}$ (NAA@ $@ 50$ ppm spray at 20 DAS) while lowest $(5.22 \mathrm{~cm})$, was recorded $\mathrm{T}_{9}$ (control). It may be due to decreased apical growth and increase in translocation of food reserves to stem. Similar result was observed with promoters in onion by Shakhada and Gajipara (1998). Among all the treatment minimum days to first flowering (31.47 days), 50 percent (40.40 days) and first harvesting (37.02 days), days to require to fruit maturity $\mathrm{T}_{4}$ (NAA @ 50 ppm sprays at 20 DAS) was recorded and followed by $\mathrm{T}_{7}\left(\mathrm{GA}_{3} @ 20\right.$ ppm at $20 \mathrm{DAS}+\mathrm{NAA} @ 50$ ppm at 40 DAS).

Similar result was reported by Chandiniraj et $a l$. , (2016) where spray of NAA @ 75 ppm had earliest flowering in chilli. Similar results have been confirmed by Natesh et al., (2005). The increased synthesis of auxin in the root tissue by their enhanced activity due to the application of NAA and their simultaneous transport to the axillary buds would have resulted in a better sink for the mobilization of photo- assimilates at a faster rate. This would have helped in the early transformation from the vegetative phase to reproductive phase. The induction of early flower bud initiation might be influenced by narrowing of the significant accumulation of carbohydrates. The result on earliness in flowering in this experiment goes with the reports by Singh and Mukherjee (2000) in chilli.

Effect of growth regulators on yield parameters of okra cv. Utkal Gaurav

Significant maximum (Table 2) fruit length $(16.58 \mathrm{~cm})$, fruit girth $(6.46 \mathrm{~cm})$, fresh fruit weight (16.47gm) and dry fruit weight (5.61) were recorded in the $\mathrm{T}_{5}$ (NAA @ 50 ppm at 40 DAS $)$ followed by $\mathrm{T}_{7}\left(\mathrm{GA}_{3} @ 20 \mathrm{ppm}\right.$ at 20 DAS and NAA @ 50 ppm at 40 DAS). Similar results were reported by Chattopadhyay and Sen (1974). The increased fruit length, girth may be due to the increase in number of leaves resulting in increased photosynthesis and maximum distribution of assimilates. These results have been reported by Kore et al., (2003).

Table.1 Effect of foliar spray of growth regulators on different growth parameters in Okra cv. Utkal Gaurav

\begin{tabular}{|c|c|c|c|c|c|c|}
\hline Treatment & $\begin{array}{l}\text { Final } \\
\text { height } \\
(\mathrm{cm})\end{array}$ & $\begin{array}{l}\text { Stem girth } \\
\quad(\mathrm{cm})\end{array}$ & $\begin{array}{l}\text { Days to } \\
\text { first } \\
\text { flowering }\end{array}$ & $\begin{array}{c}\text { Days to } 50 \\
\text { per cent } \\
\text { flowering }\end{array}$ & $\begin{array}{c}\text { First } \\
\text { harvesting }\end{array}$ & $\begin{array}{c}\text { Days require } \\
\text { to fruit } \\
\text { maturity }\end{array}$ \\
\hline $\mathrm{T}_{1}-\mathrm{GA}_{3} @ 50 \mathrm{ppm}$ at $20 \mathrm{DAS}$ & 101.32 & 5.54 & 33.11 & 43.91 & 40.27 & 68.51 \\
\hline $\mathrm{T}_{2^{-}} \mathrm{GA}_{3} @ 50 \mathrm{ppm}$ at $40 \mathrm{DAS}$ & 107.97 & 5.47 & 35.87 & 45.15 & 42.24 & 71.30 \\
\hline $\mathrm{T}_{3^{-}} \mathrm{GA}_{3} @ 50 \mathrm{ppm}$ at $60 \mathrm{DAS}$ & 98.23 & 5.26 & 38.58 & 47.94 & 44.16 & 72.47 \\
\hline $\mathrm{T}_{4}$-NAA@ $90 \mathrm{ppm}$ at $20 \mathrm{DAS}$ & 100.75 & 5.68 & 31.47 & 40.40 & 37.02 & 66.02 \\
\hline $\mathrm{T}_{5}$-NAA @ 50 ppm at 40 DAS & 104.31 & 5.46 & 36.04 & 45.36 & 43.08 & 71.13 \\
\hline $\mathrm{T}_{6}$-NAA @50 ppm at 60 DAS & 97.97 & 5.37 & 38.17 & 47.87 & 44.23 & 70.90 \\
\hline $\begin{array}{l}\mathrm{T}_{7}-\mathrm{GA}_{3} @ 20 \mathrm{ppm} \text { at } 20 \mathrm{DAS}+ \\
\mathrm{NAA} @ 50 \mathrm{ppm} \text { at } 40 \mathrm{DAS}\end{array}$ & 103.31 & 5.63 & 33.08 & 42.05 & 39.72 & 68.14 \\
\hline $\begin{array}{l}\text { T8-NAA @ } 40 \mathrm{ppm} \text { at } 20 \mathrm{DAS} \\
+\mathrm{GA}_{3} @ 50 \mathrm{ppm} \text { at } 40 \mathrm{DAS}\end{array}$ & 100.24 & 5.51 & 33.96 & 44.24 & 40.87 & 70.23 \\
\hline $\mathrm{T}_{9}$-Control & 95.07 & 5.22 & 39.04 & 49.33 & 45.14 & 76.34 \\
\hline Mean & 101.02 & 5.46 & 34.59 & 45.14 & 41.86 & 70.56 \\
\hline $\operatorname{SEm}( \pm)$ & 1.75 & 0.13 & 0.92 & 1.12 & 0.86 & 0.72 \\
\hline CD 5\% & 5.24 & 0.39 & 2.77 & 3.35 & 2.57 & 2.15 \\
\hline
\end{tabular}


Table.2 Effect of foliar spray of growth regulators on different yield parameters in okra cv. Utkal Gaurav

\begin{tabular}{|c|c|c|c|c|c|c|}
\hline Treatment & $\begin{array}{l}\text { Fruit fresh } \\
\text { weight }(g)\end{array}$ & $\begin{array}{l}\text { Dry fruit } \\
\text { weight }(g)\end{array}$ & $\begin{array}{l}\text { Fruit } \\
\text { length } \\
(\mathrm{cm})\end{array}$ & $\begin{array}{l}\text { Fruit girth } \\
(\mathrm{cm})\end{array}$ & $\begin{array}{l}\text { Fruit yield/ } \\
\text { plot }(\mathrm{kg})\end{array}$ & $\begin{array}{l}\text { Yield } \\
\text { (q/ha) }\end{array}$ \\
\hline $\mathrm{T}_{1^{-}} \mathrm{GA}_{3} @ 50 \mathrm{ppm}$ at $20 \mathrm{DAS}$ & 14.47 & 4.47 & 14.72 & 5.75 & 4.43 & 88.62 \\
\hline $\mathrm{T}_{2^{-}} \mathrm{GA}_{3} @ 50 \mathrm{ppm}$ at $40 \mathrm{DAS}$ & 14.33 & 4.53 & 13.91 & 6.25 & 4.58 & 91.52 \\
\hline 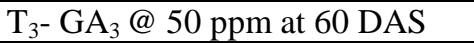 & 12.87 & 4.41 & 12.72 & 5.51 & 4.33 & 86.56 \\
\hline $\mathrm{T}_{4}$-NAA @ 50 ppm at $20 \mathrm{DAS}$ & 15.01 & 4.73 & 14.38 & 5.36 & 4.32 & 86.44 \\
\hline $\mathrm{T}_{5}$-NAA @ $50 \mathrm{ppm}$ at $40 \mathrm{DAS}$ & 16.47 & 5.61 & 16.58 & 6.46 & 4.83 & 96.63 \\
\hline $\mathrm{T}_{6}$-NAA @ $50 \mathrm{ppm}$ at $60 \mathrm{DAS}$ & 12.22 & 4.39 & 13.07 & 5.62 & 4.35 & 87.12 \\
\hline $\begin{array}{l}\mathrm{T}_{7}-\mathrm{GA}_{3} @ 20 \mathrm{ppm} \text { at } 20 \mathrm{DAS}+ \\
\mathrm{NAA} @ 50 \mathrm{ppm} \text { at } 40 \mathrm{DAS}\end{array}$ & 15.14 & 4.97 & 14.98 & 5.97 & 4.63 & 92.60 \\
\hline $\begin{array}{l}\mathrm{T}_{8} \text {-NAA@ @ } 40 \mathrm{ppm} \text { at } 20 \mathrm{DAS}+ \\
\mathrm{GA}_{3} @ 50 \mathrm{ppm} \text { at } 40 \mathrm{DAS}\end{array}$ & 12.67 & 4.35 & 13.51 & 5.68 & 4.42 & 88.40 \\
\hline $\mathrm{T}_{9}$-Control & 11.67 & 4.03 & 10.89 & 4.97 & 3.97 & 79.37 \\
\hline Mean & 13.87 & 4.61 & 13.86 & 5.73 & 4.42 & 88.58 \\
\hline SEm \pm & 0.31 & 0.17 & 0.34 & 0.18 & 0.13 & 2.01 \\
\hline $\mathrm{CD} \%$ & 0.94 & 0.50 & 1.02 & 0.55 & 0.40 & 6.02 \\
\hline
\end{tabular}

Table.3 Effect of foliar spray of growth regulators on different seed quality parameters in Okra cv. Utkal Gaurav

\begin{tabular}{|c|c|c|c|c|c|c|c|}
\hline Treatment & $\begin{array}{c}\text { Test } \\
\text { weight } \\
\text { (g) }\end{array}$ & $\begin{array}{l}\text { Shoot } \\
\text { length } \\
(\mathrm{cm})\end{array}$ & $\begin{array}{l}\text { Root } \\
\text { length } \\
(\mathrm{cm})\end{array}$ & $\begin{array}{c}\text { Fresh } \\
\text { seedling } \\
\text { weight } \\
\text { (g.) }\end{array}$ & $\begin{array}{c}\text { Dry } \\
\text { seedling } \\
\text { weight } \\
\text { (mg.) }\end{array}$ & $\begin{array}{l}\text { Vigour } \\
\text { index } \\
\text { type - I }\end{array}$ & $\begin{array}{l}\text { Vigour } \\
\text { index } \\
\text { type - II }\end{array}$ \\
\hline $\mathrm{T}_{1-}-\mathrm{GA}_{3} @ 50 \mathrm{ppm}$ at $20 \mathrm{DAS}$ & 7.00 & 15.40 & 8.43 & 5.89 & 24.33 & 2184.50 & 22.30 \\
\hline $\mathrm{T}_{2^{-}}-\mathrm{GA}_{3} @ 50 \mathrm{ppm}$ at $40 \mathrm{DAS}$ & 7.17 & 15.58 & 8.56 & 5.81 & 24.50 & 2092.21 & 21.23 \\
\hline $\mathrm{T}_{3^{-}}-\mathrm{GA}_{3} @ 50 \mathrm{ppm}$ at $60 \mathrm{DAS}$ & 6.67 & 16.95 & 8.83 & 6.15 & 26.03 & 2122.47 & 21.43 \\
\hline $\mathrm{T}_{4}$-NAA @ $50 \mathrm{ppm}$ at $20 \mathrm{DAS}$ & 6.33 & 14.83 & 8.67 & 5.69 & 24.57 & 1950.50 & 20.39 \\
\hline $\mathrm{T}_{5}$-NAA@ 00 ppm at $40 \mathrm{DAS}$ & 8.03 & 16.33 & 8.90 & 6.09 & 25.70 & 2161.71 & 22.02 \\
\hline $\mathrm{T}_{6}$-NAA@ @ $50 \mathrm{ppm}$ at $60 \mathrm{DAS}$ & 6.93 & 16.81 & 9.40 & 6.43 & 26.77 & 2210.29 & 22.58 \\
\hline $\begin{array}{l}\mathrm{T}_{7}-\mathrm{GA}_{3} @ 20 \mathrm{ppm} \text { at } 20 \mathrm{DAS}+ \\
\mathrm{NAA} 50 @ \mathrm{ppm} \text { at } 40 \mathrm{DAS}\end{array}$ & 7.67 & 15.97 & 7.93 & 6.03 & 24.57 & 2079.30 & 21.38 \\
\hline $\begin{array}{l}\mathrm{T}_{8} \text {-NAA @ } 90 \mathrm{ppm} \text { at } 20 \mathrm{DAS} \\
+\mathrm{GA}_{3} @ 50 \mathrm{ppm} \text { at } 40 \mathrm{DAS}\end{array}$ & 6.33 & 16.52 & 7.17 & 5.12 & 23.27 & 2029.52 & 19.94 \\
\hline $\mathrm{T}_{9}$-Control & 5.33 & 13.68 & 5.21 & 4.75 & 19.93 & 1561.64 & 16.48 \\
\hline Mean & 6.83 & 15.79 & 8.12 & 5.77 & 24.41 & 2043.57 & 20.86 \\
\hline SEm \pm & 0.11 & 0.14 & 0.10 & 0.07 & 0.19 & 50.87 & 0.44 \\
\hline CD 5\% & 0.32 & 0.22 & 0.56 & 0.43 & 0.29 & 152.50 & 211.99 \\
\hline CD $1 \%$ & - & 0.30 & 0.77 & 0.60 & 0.40 & 211.99 & 1.85 \\
\hline
\end{tabular}

Fruit yield of $4.83 \mathrm{~kg} / \mathrm{plot}$ and 96.63 (q/ha) fruit yield per hectare was recorded in $\mathrm{T}_{5}$ (NAA @ 50 ppm at 40 DAS) followed by $\mathrm{T}_{7}$ $\left(\mathrm{GA}_{3} @ 20\right.$ ppm at 20 DAS and NAA @ 50 ppm at 40 DAS) were superior to control. It is a well-established fact by several workers that increased yield is product of increased yield parameters like fruit length, width and number of seeds. The increased yield with NAA is due to greater mobilization of reserved food materials to fruit and seed, which ultimately increase the fruit length, width and number of seeds. Similar results were reported by Kishan et al., (2001). 


\section{Effect of growth regulators on seed quality parameters of okra cv. Utkal Gaurav}

Among the growth regulator (Table 3) maximum test weight was maximum (8.03gm) in $\mathrm{T}_{5}$ (NAA @ 50 ppm at $40 \mathrm{DAS}$ ). Similar results were reported by Godara et al., (2013). This may be due to better diversion of photosynthesis to the fruit and better accumulation of food reserves in the seeds. Similar results have been confirmed by Bhat and Singh (1997).

Growth regulator improved the seed quality parameters over control i.e. $\mathrm{T}_{6}$ (NAA @ 50 ppm spray at 60 DAS) recorded maximum root length $(9.40 \mathrm{~cm})$, fresh seedling weight $(6.43 \mathrm{~g})$, dry seedling weight $(26.77 \mathrm{mg})$ and Vigour index type-I \& II (2210.29 and 22.58). Similar result was reported by Premchand et al., (2013). Seeds become more viable and vigorous due to proper development of embryo and endosperm by proportionate use of growth regulators. Similar result was recorded in Khan et al., (2013).These results are in conformity with that of Baruah \& Paul (1997) and Velumani and Ramaswamy (1977)

On the basis of results obtained during the present investigation reveals that use of growth regulators (foliage spray) enhanced the growth, yield and seed quality parameters of okra So, it can be concluded that foliar spray of $\mathrm{T}_{5}$ (NAA @ 50 ppm 40 days after sowing) is most effective in enhancing the yield of okra and improved the seed quality parameters $\mathrm{T}_{6} \mathrm{NAA} @ 50$ ppm spray at 60 DAS.

\section{References}

Abdul-Baki, A.A., and Anderson, V.D., 1973. Vigour determination in soybean seedmultiple criteria. Crop science, 13:630-633.

Baruah, G.K.S., and Paul, S.R. 1997. Seed development and maturation studies in okra. Annual Agriculture Research. 18(1): 367-368.

Bhatt, K.L., and Singh, A.K. 1997. Effect of different levels of phosphorus, gibberellic acid and picking on seed production of okra (Abelmoschus esculentus (L.) Moench). Vegetation Science. 24(1): 4-6.

Chandiniraj, A., Holebasappa, K., Hore, J.K. and Chattopadyay, N. 2016. Growth and yield of chilli (Capsicum annuum L.) as influenced by different growth regulators. The BIOSCAN the Journal an International Quarterly Journal of life sciences. 11(1): 385-388.

Chattopadhyay, J.K., and Sen, S.K. 1974. Studies on the effect of different growth regulators on reproductive physiology and morphology of chilli. Vegetable Science. 1: 41-46.

Godara, A.S., Gupta, U.S., Singh, R. and Lal, G. 2013. Effect of bio-regulators on productivity and profitability of fenugreek (Trigonella foenum-graecum L.). International Journal Seed Spices. 3(2):42-45.

Khan, S.H., Chattoo, M.A. and Mufti, S. 2013. Effect of plant bio-regulators on seed yield, germination and vigour in okra [Abelmoschusesculentus (L.)Moench]. Progressive Horticulture. 45(2): 345-346.

Kishan, S.T.V., Sharma, R.S. and Attri, B.L. 2001. Effect of Alpha napthalene acetic acid and 2-4-D on growth quality and yield of tomato cultivars. Madras Agriculture Journal. 30(10-12): 723726.

Kore, V.N., A. R. Salunke, S. Gargi, A.V. Mane, R. Patil and Bendale V.W. 2003. Flowering and yield attributes of okra as influenced by different plant growth regulators. Journal of Soils and Crops. 13(2): 238-241.

Natesh, N., Vyakaranahal, B.S., Gouda, M.S. 
and Deshpande, V.K. 2005. Influence of growth regulators on growth, seed yield and quality of chill cv. Byadgikaddi. Karnataka Journal of Agricultural Sciences. 18(1):36-38.

Patil, D.R., and Patel, M.N. 2010. Effect of seed treatment with $\mathrm{GA}_{3}$ and NAA on growth and yield of okra [Abmelmoschus esculentus (L.) Moench] cv. GO-2. The Asian Journal of Horticulture. 5(2): 269-272.

Premchand, K., Channakeshava, B.C. and Narayanareddy, A.B. 2013. Effect of Interaction due to Plant Growth Regulators and Fruit Retention on Crop Growth, Seed Yield and Quality in Okra cv. Arka Anamika. Indian Horticulture Journal. 3(2): 10-18.

Rani, M.U., U.K. Jyothi, and Kumar, M.K. 2013.Study on the effect of growth regulators and micronutrients on yield components and nutrient uptake of okra (Abelmoschus esculentus L. Moench cv. Arka Anamika. International Journal of Agriculture Environment \& Biotechnology. 6(1): 117-119.
Shakhada, V.P., and Gajipara, N.N. 1998. A note on influence of NAA, IBA and $\mathrm{GA}_{3}$ on growth and yield of onion (Allium cepa L.). Vegetable Science. 25:123-125

Singh, J., B.K. Singh, A.K. Singh, M. Panwar, and Singh B. 2012. Effect of foliar spray of $\mathrm{GA}_{3}$ and IBA on plant characters and yield of okra [Abelmoschus esculentus (L.) Moench]. Environment \& Ecology. 30(4): 13511353.

Singh, L., and Mukherjee, S. 2000. Effect of foliar application urea and NAA on yield and yield attributes of chilli (Capsicum апnиum var: longum). Agriculture Science Digest. 20(2):116117.

Taiz, L., Zeiger, E., Moller, I.M. and Murphy. A. 2010. Gibberellins Regulators of Plant Height. Plant Physiology. 5:461492.

Velumani, N.P., and Ramaswamy, R.R. 1977. Studies on fruit development and maturation in okra. (Abelmoschus esculentus (L.) Moench). Indian Journal Horticulture.283-285.

\section{How to cite this article:}

Kanhaiyalal Sanodiya, Geeta Pandey, Prafull Kacholli and Ashish Kumar Dubey. 2017. Effect of Growth Regulator on Growth, Yield and Seed Quality Parameters of Okra (Abelmoschus esculentus L.): cv. Utkal Gaurav. Int.J.Curr.Microbiol.App.Sci. 6(10): 3551-3556. doi: https://doi.org/10.20546/ijcmas.2017.610.418 